\title{
MENSWAARDIGHEID:
}

\section{TEMA BINNE SUID-AFRIKAANSE GEREFORMEERDE TEOLOGIE? ${ }^{1}$}

Dirkie Smit

Universiteit van Stellenbosch

\begin{abstract}
For the major part of the twentieth century human dignity has not been a theme in Reformed theology in South Africa. Rather, Reformed theological anthropology was influenced by other philosophical questions and ideological trends. When human dignity became a theme late during the century, it was mainly employed as critical notion over against forms of injustice and exclusion, and therefore mainly in political and legal uses, often directly related to human rights. By the time it found expression in the first democratic Constitution (1996) it had almost become commonplace in public life. As result of this particular history, several discourses concerning human dignity can today be discerned in South African society and Reformed churches and theologians are involved in all of them, also by way of different theological and inter-disciplinary research projects. This paper provides a brief overview of this history and concludes by distinguishing some of the contemporary discourses.
\end{abstract}

Sleutelwoorde: Gereformeerde Teologie, Menswaardigheid, Menseregte, Teologiese antropologie

Menswaardigheid was nie 'n tema binne Suid-Afrikaanse gereformeerde teologie vir die grootste deel van die 20ste eeu nie. Gereformeerde teologiese antropologie is deur ander vraagstellings en strominge beïnvloed. As dit later geleidelik wel tot tema word, is dit grootliks as kritiese begrip téénoor vorme van verontregting en uitsluiting, en daarom hoofsaaklik in 'n politieke en juridiese betekenis, in direkte samehang met menseregte. As dit uiteindelik in die Grondwet van die Republiek van Suid-Afrika (1996) neerslag vind, word dit wyd aanvaar as byna 'n vanselfsprekende gegewenheid. Vanweë dié geskiedenis kan daar vandag verskeie diskoerse rondom menswaardigheid onderskei word wat tegelyk in die Suid-Afrikaanse samelewing gevoer word, en ook gereformeerde kerke en teoloë neem aan die meeste daarvan deel, ook deur talle navorsingsprojekte.

\section{Apartheid en gereformeerde antropologie?}

Antropologiese diskoerse binne die apartheidsdenke het berus op kollektivistiese sieninge van die mens - in terme van groep en gemeenskap, kultuur en taal, afkoms en bloed, volk en ras - en nie op enige belangstelling in die persoon of die individu, en daarmee ook die waardigheid van die persoon nie. Die gereformeerde teologie wat in apartheidskringe beoefen is het hierdie diskoerse weerspieël en meermale begrond en gevoed. Dit het

Verwerking van lesing gelewer tydens konsultasie van Teologiese Fakulteit van die Universiteit van Stellenbosch en die Protestantse Theologische Universiteit Kampen op 10-11 Oktober 2005, Kampen, Nederland. 
grootliks gegeld van sowel dogmatiese en etiese, bybels-teologiese en eksegetiese, historiese, prakties-teologiese en missiologiese werk. In positiewe sin was die gemeenskap meesal in die fokus wanneer oor menswees gedink is. In negatiewe sin is humanisme (saam met liberalisme) konsekwent gebruik as sambreelterm vir verleidelike denkwyses wat die apartheidsideologie - en die gereformeerde geloof en lewensbeskouing - fundamenteel bedreig het. Wanneer in dié tyd wel teologies oor menseregte gepraat word, is dit meesal negatief, selfs afwysend (soos byvoorbeeld ook nog in die NGK se amptelike studiestuk Ras, Volk, en Nasie en Volkereverhoudinge in die lig van die Skrif, 1974).

Sedert die 60er jare het daar teologiese belangstelling ontwikkel binne gereformeerde geledere - meesal in prakties-teologiese kringe (soos homiletiek en pastoraat), maar ook in meer filosofiese, dogmatiese en etiese kringe, om op abstrakte wyse oor "die moderne mens" te praat, wat dan wel as enkeling, individu of persoon gesien is - soms positief, soms negatief, meesal bloot beskrywend - maar dié moderne mens is meer in terme van universele antropologiese eksistensiale gesien en beskryf as in verband met menswaardigheid. Die invloed van Europese filosofiese ontwikkelinge is baie duidelik, veral by sommige Suid-Afrikaanse teoloë wat in Europa verder studeer het (byvoorbeeld Bethel Müller; Hennie Rossouw; Johan Heyns).

In die akademiese gereformeerde dogmatiek was die antropologie eweneens nie werklik 'n selfstandige en baie sentrale tema nie. Wanneer dit wel in dogmatiekhandboeke of selfs in monografieë behandel is, was die benadering meesal tradisioneel gereformeerd, en was tradisionele temas - byvoorbeeld rondom sonde, dood, die beeld Gods, die verbond - aan die orde, en menswaardigheid (en ook menseregte) algeheel afwesig (byvoorbeeld Heyns, Dogmatiek, 1978; Adrio König, Bondgenoot en Beeld, 1991).

Selfs in akademiese gereformeerde etiek ontbreek enige besinning oor menswaardigheid en menseregte (in Heyns se omvattende drie-bandige Teologiese Etiek $(1982,1986,1989)$ word dit byvoorbeeld slegs op twee bladsye bespreek, en nie eens onder 'n eie opskrif nie). In die dominante openbare lewe en die openbare meningsvorming binne die apartheidsamelewing - insluitende die koerante, radio en later die televisie - was menswaardigheid en menseregte in dié tyd 'n totaal ontoelaatbare term, en die dominante akademiese gereformeerde teologie en etiek van die dag het dié taboe versterk en op geen manier teëgegaan nie. Dit word beskou as tegelyk - teologies - (goddelose) humanisme en polities - 'n (goddelose) kommunistiese aanslag.

\section{Die apartheidstryd en gereformeerde antropologie?}

In die teologiese denke binne die verset en die stryd téén apartheid - veral in die eerste dekades - was uitdruklik antropologiese argumente nie eintlik sentraal nie, en definitief nie diskoerse gebou op menswaardigheid nie. Veral binne gereformeerde teologiese kringe was ander motiewe soos kerkeenheid en versoening eerder die vertrekpunte vir kritiek op en die verwerping van die apartheidsideologie, -teologie en -ekklesiologie. Dit het waarskynlik saamgehang met die feit dat vorme van natuurlike teologie apartheid grootliks onderbou het (na die motto: "die herskepping hef nie die skepping op nie, maar vervolmaak dit", uitgelê as: die gegewe volkereverskeidenheid in die skepping behoort die lewe in die kerk en tussen gelowiges te struktureer en te normeer). Die sterkste kritiek op dié soort gereformeerde teologie het gekom van kringe wat beïnvloed was deur Barth, Barmen, Bonhoeffer en die Belydende Kerk en hulle klem op Christus, die Woord, die Nuwe Testament, die kerk, die eenheid en versoening in Christus, die bevryding in Christus (laasgenoemde byvoorbeeld Allan Boesak se talle werke sedert Farewell to innocence, 1976; ook nog John 
de Gruchy se Liberating reformed theology, 1991, wat verskeie gereformeerde motiewe uitwerk, maar nie van die antropologie of menswaardigheid 'n eie tema maak nie).

In sommige ander kerklike en teologiese tradisies was dit deurgaans byna voor-diehand-liggend om oor die antropologie te dink en skryf op maniere wat die apartheidsdenke sou ondermyn en tegelyk menswaardigheid en menseregte positief sou bepleit en bevorder (reeds Steve Biko en Manas Buthelezi in The challenge of black theology in South Africa, 1973; Simon Maimela; Desmond Tutu; vandag nog Njongonkulu Ndungane; die Southern African Catholic Bishops' Conference, byvoorbeeld Human rights and repression in South Africa, 1989). Ook die ekumeniese Suid-Afrikaanse Raad van Kerke was deurgaans betrokke by talle bewegings, organisasies, inisiatiewe, aksies en publikasies (byvoorbeeld reeds Human rights in South Africa, red. Brian Johanson, 1974) tot dit in die vroeë 80er jare 'n spesiale Kommissie vir Menseregte gestig het, wat onder andere oor 'n teologiese basis sou besin (terwyl menseregte steeds algeheel onaanvaarbaar en verdag was in die dominante openbare mening van die tyd).

Geleidelik sou gereformeerde teoloë dit egter ook toenemend begin doen. Belangrike bydraes vanuit gereformeerde kringe wat in hierdie tyd - alhoewel op uiteenlopende wyses - op grond van antropologiese argumente apartheidsdenke kritiseer, is byvoorbeeld Jaap Durand, Skepping, mens, voorsienigheid (1982), Boesak (in Apartheid is a Heresy, 1983, teenoor rassisme), Danie du Toit (as redakteur, Menseregte, 1984), Bernard Lategan, Johann Kinghorn, Lourens du Plessis en Etienne de Villiers, Die keuse vir 'n inklusiewe demokrasie (1987), Du Toit, Die mens en sy regte (1988), Kinghorn, 'n Tuiste vir almal (1990, oor demokrasie, maar met uitdruklike bespreking van menseregte). As Nuwe Testamentikus skryf Lategan oor die antropologie, met duidelik etiese en sosiale bedoelinge. In 'n studiestuk van die NGSK oor rassisme speel argumente rondom mense as beelddraers van God 'n teologiese sleutelrol (1982). Die amptelike studiestuk van die NGK, Kerk en Samelewing (1986, hersien 1990) praat ook wel in baie sterk taal oor geregtigheid, maar nie in terme van menswaardigheid of menseregte nie, dog meesal eerder in terme van geregtigheid teenoor alle "groepe", waar onder egter veral ook die weerloses. In hierdie tyd begin gereformeerde teoloë dus ook van menswaardigheid praat, maar meer nog van menseregte, en die politieke konnotasies is duidelik op die voorgrond.

In die werkingsgeskiedenis van die gereformeerde Belydenis van Belhar $(1982,1986)$, wat self ook nie uitdruklik antropologies argumenteer nie en nie die terme menswaardigheid of menseregte gebruik nie, word die voorstelling dat God op 'n besondere wyse die God van die noodlydendes, die armes en die veronregtes is en die kerk roep om daarin na te volg toenemend gebruik vir die appèl dat die kerk ook - soos die Hulp van die hulpeloses mense "in enige vorm van lyding en nood" behoort by te staan. Gedurende die laat $80 \mathrm{er}$ jare word dit al hoe meer algemeen, ook in hierdie gereformeerde kringe, om die waardigheid van alle slagoffers, alle lydendes en uitgeslotenes, te bely - kinders, ouer persone, vroue, siekes, vigs-slagoffers, gestremdes, armes, veronregtes, homofiele, vreemdelinge (talle studies, insluitende Denise Ackermann, alhoewel self nie gereformeerd nie, Christina Landman, Mary-Anne Plaatjies, Elna Mouton; ook byvoorbeeld Eddie Bruwer, Beggars can be choosers, 1994; Ernst Conradie en andere, oor verkragting in Rape: Rethinking male responsibility, 2003). Hiermee word die voorstelling van menswaardigheid tot 'n kritiese begrip, tot weerstand teen die algemene neiging om mense te beoordeel op grond van wat hulle werd is volgens sosiale en kulturele maatstawwe, om hulle volgens hulle sukses en nuttigheid te klassifiseer en te behandel. Teologies speel lutherse gedagtes rondom die onderskeid tussen mense en hulle werke (Jüngel; Huber) en die leer van die regverdigverklaring van die goddeloses hierin 'n belangrike rol, maar óók voorstellinge uit die gereformeerde verkiesingsleer (insluitende Bavinck). 


\section{Demokrasie en gereformeerde antropologie?}

Met die oorgang na 'n pluralistiese, demokratiese samelewing (1994) word sowel menswaardigheid (in die inleiding) as menseregte (in 'n uitvoerige en hoogs liberale handves van vryhede) in die nuwe Grondwet van die Republiek van Suid-Afrika (1996) ingeskryf. Enersyds vervul dit 'n negatiewe en kritiese rol (in die ideale van 'n nie-rassige, nie-seksistiese visie en verbintenis), andersyds vervul dit 'n positiewe en konstruktiewe rol (in die gedetailleerde beskrywing van individuele en sosiale vryhede en regte). In die openbare mening en die politieke debatte word dit nou 'n vanselfsprekendheid. Niemand twyfel eintlik meer in die openbaar daaraan nie - juis ook die vroeëre kritici sien dit nou as 'n belangrike instrument om hulle eie belange te beskerm, insluitende privaatbesit, vryheid van spraak en assosiasie, en die taal, kulturele en godsdienstige regte van minderhede. Ook in gereformeerde kringe - kerklik én teologies - word menseregte nou deel van die gewone spreek- en denkwyses (sien byvoorbeeld die studies van JM (Koos) Vorster; ook die bundel Building a human rights culture, Karin Sporre \& Russel Botman, redakteurs, 2003 met bydraes van Ackermann, Nico Koopman en Conradie, met Sweedse samewerking).

'n Nuwe belangstelling in teologiese antropologie word nou herkenbaar in gereformeerde teologiese kringe, waarin byvoorbeeld verskeie aspekte van die Triniteitsleer meermale ontgin word met die oog op moontlike implikasies vir antropologie en etiek (só Robert Vosloo, "Being created in the image of the Triune God: the Trinity and human personhood," REC 1999; ook verskeie bydraes van Koopman). Conradie publiseer 'n uitgebreide ekologiese antropologie (At home on earth?, 2005). Die enigste teologiese titel in die universiteitsbiblioteek van Stellenbosch met die term "menswaardig" verskyn in dié tyd, Menswaardig (1994), opstelle onder redaksie van gereformeerde praktiese teoloë van Pretoria, Cas Vos en Julian Müller. Dit bevat meesal preke rondom mens en menslikheid, maar ook inleidende opstelle van onder andere König, almal oor waarde, waardigheid en menseregte.

$\mathrm{Na}$ die eerste dekade van omvattende sosiale transformasie blyk tans toenemend dat die menswaardigheid en veral ook die sosiale en ekonomiese regte wat die Grondwet voorsien in die praktyk - polities, juridies, maatskaplik, ekonomies, opvoedkundig, in sosiale versorging en dienste - tot 'n baie hoë mate nog nie deur die uitgeslotenes en slagoffers ontvang en beleef word nie. Juriste, ekonome en ook teoloë uit die gereformeerde tradisie (veral uit die kringe van die Beyers Naudé Sentrum vir Publieke Teologie) vra saam na moontlike redes hiervoor, óf in die gebrekkige teoretiese raamwerke, óf in gebrekkige veranderinge in die openbare mening (sien AJ van der Walt, Theories of Social and Economic Justice, 2005, met bydraes deur Koopman, Fanie du Toit en myself). Interdissiplinêre navorsing word gedoen oor die moontlike vermensliking van die ekonomie, en veral die effek van ekonomiese globalisering op Suid-Afrika (sien byvoorbeeld Koopman, in The legacy of Beyers Naudé. The Beyers Naudé Centre Series on Public Theology, Vol. 1, 2005; ook 'n bundel opstelle van die Akademies Arnoldshain en Bad Boll saam met die Beyers Naudé Sentrum, 2007).

\section{Huidige diskoerse rondom menswaardigheid?}

Onlangse werk van Botman (toe reeds President van die Suid-Afrikaanse Raad van Kerke, tans ook rektor van Stellenbosch Universiteit) verdien spesiale aandag as gevolg van die heuristiese helderheid en nut. Hy skryf self verskillende antropologiese bydraes oor byvoorbeeld menswaardigheid en die globale ekonomie. In 'n voordrag "Towards a covenantal anthropology" - binne die konteks van 'n internasionale, inter-dissiplinêre navorsingsprojek geïnisieer deur die CTI, Princeton NJ - onderskei hy twee huidige post- 
apartheid diskoerse oor menswaardigheid in Suid-Afrika, te wete "die diskoers van gelykheid" en "die diskoers van versoening". Die eerste dui op die diskoers wat die oorgang tot demokrasie begelei het en steeds 'n fundamentele rol speel. Die tweede dui op die diskoers wat helende herinnering aan die grusaamhede van die verlede probeer bevorder het en wat veral rondom die werksaamhede van die Waarheids- en Versoeningskommissie 'n sleutelfunksie vervul het, en steeds bly vervul. Self pleit hy dan vir die belang van 'n derde diskoers oor menswaardigheid, en wel in die aangesig van die mensonterende werklikheid van toenemende ekonomiese globalisering, veral soos dit die vasteland van Afrika raak. In 'n tipies gereformeerde teologiese argument ontwikkel hy "die teologies-antropologiese metafoor" van die verbond as 'n manier om al drie hierdie diskoerse rondom menswaardigheid met mekaar te integreer.

Die heuristiese waarde van Botman se werk lê nie alleen in sy eie analise van die drie diskoerse nie, maar meer nog in die benadering wat hy aandui, naamlik om verskillende diskoerse rondom menswaardigheid te probeer onderskei, in die Suid-Afrikaanse openbare meningsvorming, maar dalk daarom ook in gereformeerde kerklike en teologiese kringe. In navolging daarvan sou 'n mens waarskynlik vandag samevattend ook kon praat van diskoerse rondom individuele regte (dikwels geïnstrumentaliseer, nie altyd langer as beskerming van die swakkes nie maar meermale as handhawing van bevoorregting, of in diens van 'n kultuur van toeëiening), diskoerse rondom minderheidsregte (wat sowel rondom taal, as kultuur, as godsdiens, as grondbesit en territoriale soewereiniteit telkens weer brandend word en opnuut opvlam met intensiteit), kritiese diskoerse rondom die beskerming van slagoffers, benadeeldes en weerloses (telkens met verskillende name en gesigte, maar uiteindelik tog dikwels met armoede as gemeenskaplike of verswarende faktor, agter insidente te make met onderwys, gesondheidsorg, veroudering, onversorgde weeskinders, behuisingsnood, werkloosheid, vigs en ander siektes), diskoerse rondom eenheid en solidariteit en onderlinge sorg (dikwels rondom vrae van behoort, van vreemdelinge, van gasvryheid, van verwelkoming in skole, woonbuurte, tersiêre omgewings; of rondom blywende ervarings van vooroordeel en rassisme, asook diepliggende sosiale en strukturele werklikhede van seksisme), diskoerse rondom gelykheid (van toegang, geleenthede, behandeling; of regstellende aksie), diskoerse rondom respek vir die ander se verhale, ervaringe, lyding en waarheid (dikwels in diens van versoening, genesing, afsluiting van die pynlike verlede), en inderdaad diskoerse rondom geregtigheid (gelykheid voor die reg, menseregte, sosiale regte, veral ekonomiese geregtigheid, gegee die erfenis van massiewe historiese ongelykhede en die ontmagtigende effek van die huidige vorm van ekonomiese globalisering).

Tans is gereformeerde teoloë waarskynlik geïnteresseerd in bykans al hierdie diskoerse - insluitende kollegas en nagraadse studente aan die Universiteit van Stellenbosch. Talle vorme van inter-dissiplinêre gesamentlike navorsing geskied reeds, sowel binne die Fakulteit as geheel (spesifiek rondom armoede), asook met ander kollegas binne die Universiteit en elders, binnelands, maar baie intensief ook in Afrika (byvoorbeeld op groot skaal rondom vigs), sowel as in verskeie ander lande. Gereformeerde kerke en teologie in Suid-Afrika is tans verbind tot diens aan menswaardigheid. 